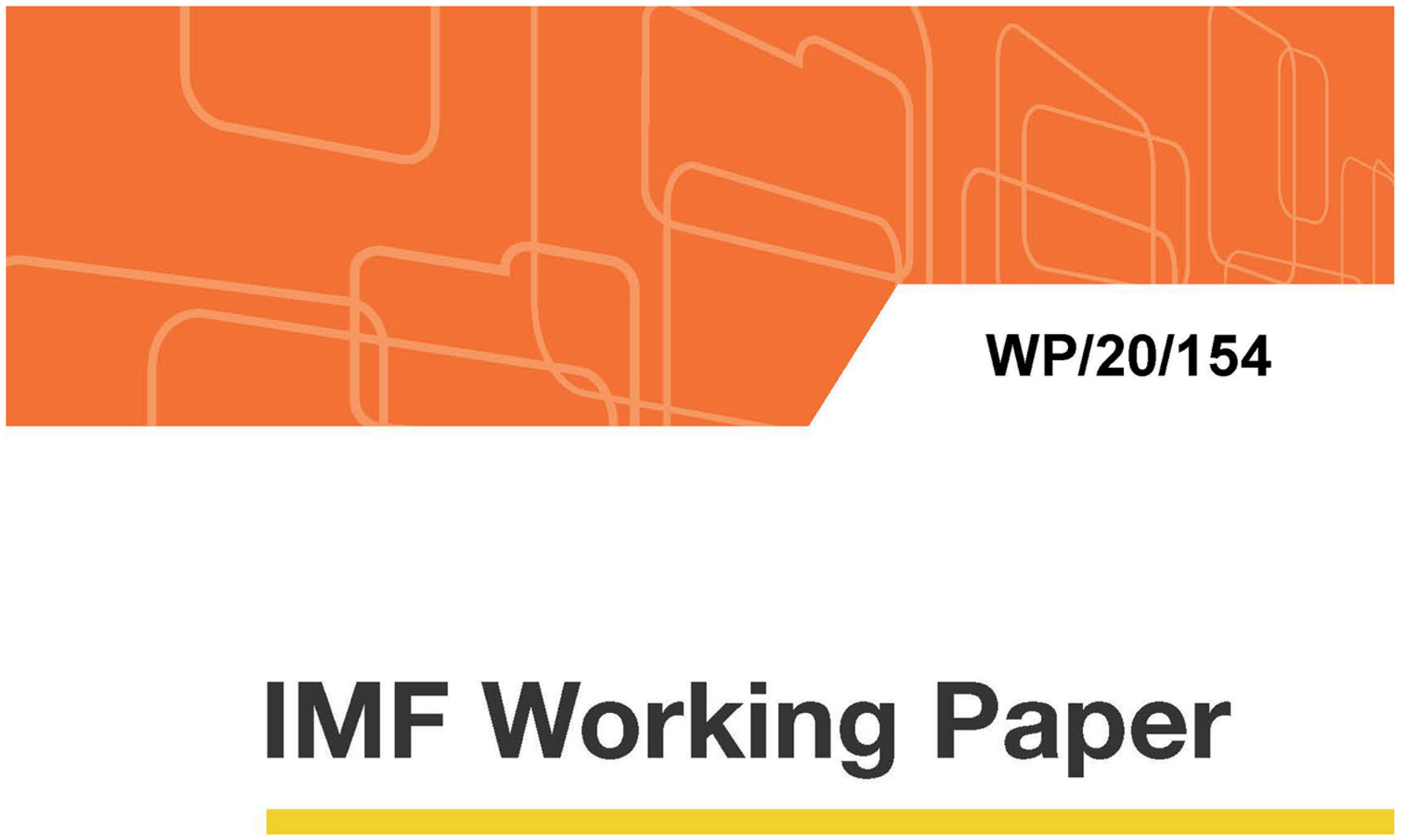

\title{
Exchange Rate Pass-Through in the Caucasus and Central Asia
}

by Tigran Poghosyan

IMF Working Papers describe research in progress by the author(s) and are published to elicit comments and to encourage debate. The views expressed in IMF Working Papers are those of the author(s) and do not necessarily represent the views of the IMF, its Executive Board, or IMF management. 


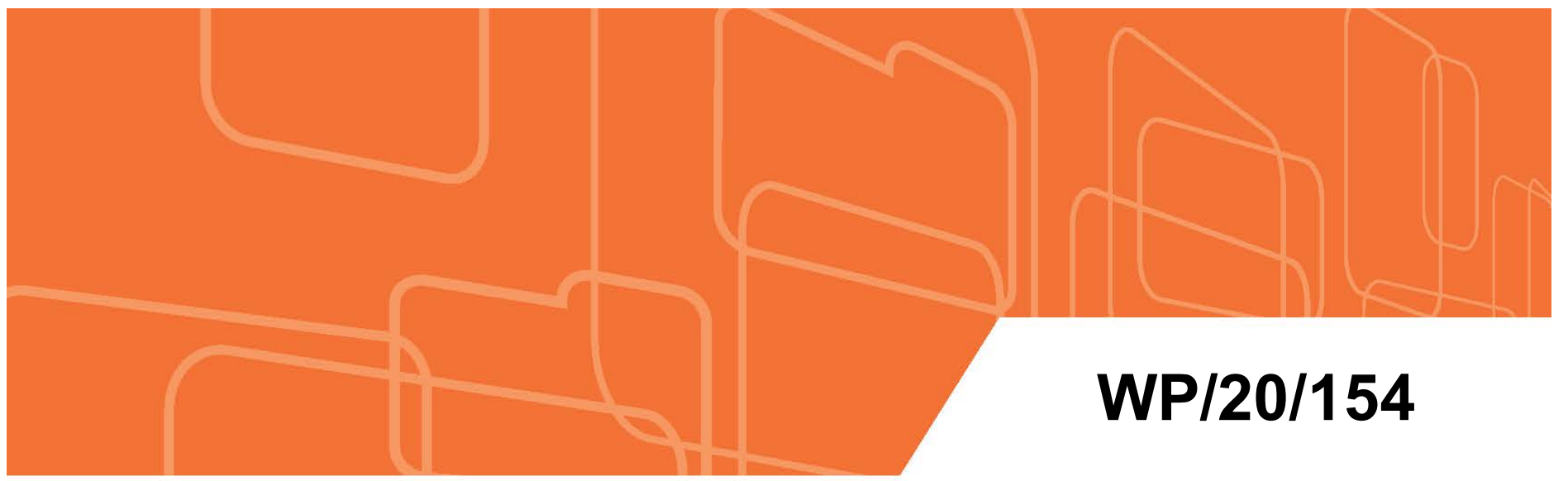

\section{IMF Working Paper}

\section{Exchange Rate Pass-Through in the Caucasus and Central Asia}

by Tigran Poghosyan

IMF Working Papers describe research in progress by the author(s) and are published to elicit comments and to encourage debate. The views expressed in IMF Working Papers are those of the author(s) and do not necessarily represent the views of the IMF, its Executive Board, or IMF management. 


\title{
IMF Working Paper
}

Middle East and Central Asia Department

\section{Exchange Rate Pass-Through in the Caucasus and Central Asia Prepared by Tigran Poghosyan ${ }^{1}$}

Authorized for distribution by Nicolas Blancher

August 2020

Disclaimer: This document was prepared before COVID-19 became a global pandemic and resulted in unprecedented economic strains. It, therefore, does not reflect the implications of these developments and related policy priorities. We direct you to the IMF Covid-19 page that includes staff recommendations with regard to the COVID-19 global outbreak.

\section{IMF Working Papers describe research in progress by the author(s) and are published to} elicit comments and to encourage debate. The views expressed in IMF Working Papers are those of the author(s) and do not necessarily represent the views of the IMF, its Executive Board, or IMF management.

\begin{abstract}
This paper estimates the extent and speed of exchange rate pass-through (ERPT) in seven Caucasus and Central Asia (CCA) countries using monthly data over the January 1995May 2020 period. The estimations are performed using the local projections method. We find that the average pass-through in the CCA is about 10 percent on impact and about 25 percent after 12 months. There is no evidence of asymmetric ERPT with respect to the size and the sign of exchange rate changes. The pass-through is broadly unchanged in fixed versus floating exchange rate regimes. There has been a downward shift in the speed of ERPT in the aftermath of the global financial crisis as CCA countries have entered a relatively low inflation environment. The pass-through estimates could be used by the CCA monetary authorities for inflation projections. The absence of non-linearities in the passthrough with respect to the exchange rate regime suggests that transition from fixed to floating exchange rate regimes in the region is not likely to impose additional inflationary costs.
\end{abstract}

JEL Classification Numbers: E31, F31

Keywords: exchange rate pass-through, inflation, exchange rate regime, local projections Author's E-Mail Address: TPoghosyan@imf.org

\footnotetext{
${ }^{1}$ I would like to thank Marwa Alnassa, Yevgeniya Korniyenko, Subir La ll, Na than Porter, Sergejs Saksonovs, and Hamid Reza Ta barraei for helpful comments and suggestions. Liliya Nigmatullina provided excellent production assistance. The usual disclaimer a pplies.
} 
Contents

Abstract

I. Introduction $\underline{4}$

II. Literature Review $\underline{5}$

III. Data and Stylized Facts $\underline{7}$

IV. Empirical Specification and Estimation Results $\underline{8}$

A. The Linear Model $\underline{8}$

B. Does ERPT Vary with the Size of Exchange Rate Changes?

C. Does ERPT Vary with the Sign of Exchange Rate Changes?

D. Does ERPT Vary with Exchange Rate Regimes?

E. Does the ERPT Differ Across Energy-Exporters and Energy-Importers?

F. Has ERPT Changed in the Post-Global Financial Crisis Period?

V. Conclusions

References

FIGURES

1. Dynamics of CPI Inflation in the CCA Countries

2. Dynamics of Exchange Rate Changes in the CCA Countries

3. Association Between CPI Inflation and Exchange Rate Changes in the CCA Countries_ 15

4. ERPT: The Linear Model

5. ERPT: The Panel VAR Model

6. ERPT: Non-Linearities for the Size of Exchange Rate Depreciation

7. ERPT: Non-Linearities for Exchange Rate Appreciation versus Depreciation

8. ERPT: Non-Linearities for Exchange Rate Regimes

9. ERPT: Non-Linearities for Pre-Crisis and Post-Crisis Periods

10. ERPT: Non-Linearities for Pre-Crisis and Post-Crisis Periods

$\frac{21}{22}$

\section{TABLES}

1. Summary of Selected Exchange Rate Pass-Through Studies

2. Variables and Their Sources $\frac{23}{25}$

3. Summary of Main Results $\underline{26}$ 


\section{INTRODUCTION}

The degree to which exchange rate changes are transmitted to inflation has been at the center of policy discussions in many countries, including in the Caucasus and Central Asia (CCA). High speed of exchange rate pass-through (ERPT) is one of the key reasons behind the "fear of floating" that many emerging and low-income countries experience (Calvo and Reinhart, 2002). In addition, the pass-through helps better understand the extent of expenditure switching (substitution between foreign and domestic goods) in response to exchange rate changes (Burstein and Gopinath, 2014). Therefore, measuring the speed of ERPT for different projection horizons has important implications for monetary policy.

This paper assesses the speed of ERPT in seven CCA countries. ${ }^{2}$ The estimations are performed using monthly data for the period January 1995-May 2020. Following an established literature on the topic, we use the local projections method to measure the passthrough. In addition to the linear pass-through, we also assess whether there are any nonlinearities or asymmetric effects associated with the size of exchange rate changes, the sign of exchange rate changes, the exchange rate regime, structural differences between energyexporting and energy-importing countries, and whether the pass-through has changed in the aftermath of the global financial crisis.

We find that the average speed of the pass-through in the CCA is about 10 percent on impact and about 25 percent after 12 months. The average pass-through in the CCA countries is somewhat higher than the pass-through in the CIS countries (Comunale and Simola, 2018) and 28 emerging economies (Caselli and Roitman, 2016), but it is lower compared to the pass-through in Sub-Saharan Africa countries (Razafimahefa, 2012). The pass-through is somewhat higher in CCA energy-importing countries compared to CCA energy-exporting countries, which could be explained by structural differences across these countries (economic diversification, reliance on remittances, proportion of imported goods in CPI baskets).

We find no evidence of asymmetric pass-through with respect to the size and the sign of exchange rate changes. Also, the pass-through is broadly unchanged in fixed versus floating exchange rate regimes. The pass-through has been higher before the global financial crisis (13 percent on impact and 35 percent after 12 months) compared to the post-crisis period ( 8 percent on impact and 20 percent after 12 months) and this difference is statistically significant. The latter finding is consistent with the evidence that the pass-through tends to be lower in a low inflation environment.

The remainder of the paper is structured as follows. Section II provides an overview of the literature. Section III discusses the data and stylized facts. Section IV presents the empirical specification, estimation results, and robustness checks. The last section concludes.

\footnotetext{
${ }^{2}$ The sa mple does not include Turkmenistan due to lack of sufficiently long time series.
} 


\section{LiterATURE REVIEW}

There is a burgeoning empirical literature on ERPT in emerging and low-income countries (Aron and others, 2014 and Burstein and Gopinath, 2014 provide exhaustive surveys). Early research on pass-through focused on transmission of exchange rate changes to local currency prices of imported goods. ${ }^{3}$ Most recently, the focus shifted to the transmission of exchange rate changes to the general price level in the economy, such as consumer prices. Changes in import prices triggered by exchange rate movements can transmit to consumer prices directly (through imported goods in the consumption basket) and indirectly (through imported inputs to domestically produced goods). In terms of the exchange rate variable, some studies have used the local currency exchange rate vis-à-vis the US dollar, while others have used the nominal effective exchange rate.

The speed of ERPT depends on the pricing strategy of importers. One extreme is the local currency pricing strategy, according to which the local currency prices of imported goods remain broadly unchanged irrespective of exchange rate movements. Under this strategy, ERPT $=0$ as importers take on the exchange rate risk and adjust their margins in response to exchange rate fluctuations. Another extreme is the producer currency pricing strategy, according to which the foreign currency prices of imported goods remain broadly unchanged in response to exchange rate movements. Under this strategy, ERPT $=1$ as importers fully pass-through exchange rate changes to consumers, who ultimately bear the exchange rate risk. In practice, the pass-through is often incomplete and is estimated somewhere in between 0 and 1. Various explanations were provided in the literature in support of the incomplete pass-through, including expenditure switching, market segmentation, imperfect competition, nominal price rigidities and menu costs (Aron and others, 2014).

Several hypotheses have been tested and stylized facts established in the literature (Table 1). There is a consensus in the literature that the speed of pass-through tends to be larger in emerging and low-income countries compared to advanced economies (Taylor, 2000; Jasova and others, 2019). This is in part explained by the fact that the level of inflation in advanced economies has been generally lower than that of emerging and low-income countries and, as shown empirically by Choudhri and Hakura (2006), there is a causal link between a low inflation environment and lower pass-through. Other explanations are related to: (i) the larger share of imported goods in the consumption baskets of emerging and low-income countries, (ii) the higher exposure of emerging and low-income countries to terms of trade shocks, and (iii) the lack of exchange rate hedging instruments in emerging and low-income countries.

Some studies have analyzed possible non-linearities and asymmetries in the pass-through. The pass-through may vary with the size of exchange rate movements, with smaller exchange rate changes producing a different proportionate response of consumer prices compared to

\footnotetext{
${ }^{3}$ Goldberg and Knetter (1997) define ERPT as "thepercentage change in local currency import prices resulting from a onepercentchange in the exchange rate between the exporting and im porting countries".
} 
larger changes. Size asymmetries may result from menu costs associated with changing prices: importers may absorb small exchange rate changes in their margins but pass through larger changes exceeding a certain threshold to consumers. The evidence on size asymmetries is mixed. For instance, Ben Cheikh (2012) for 12 euro area countries, Caselli and Roitman (2016) for 28 emerging markets, Kilic (2016) for 6 OECD countries, Comunale and Simona (2018) for 7 CIS countries, and Jasova and others (2019) for 22 emerging markets and 11 advanced economies find that the pass-through is higher for larger exchange rate movements, while Bussiere (2013) for G7 countries finds that the pass-through is lower for larger exchange rate movements.

The pass-through may also vary with the sign of exchange rate movements, with exchange rate depreciations producing a different proportionate response of consumer prices compared to exchange rate appreciations. In relatively more competitive markets, the pass-through may be higher for appreciations compared to depreciations: importers may reduce margins when local currency depreciates to stabilize the local price but keep margins unchanged when local currency appreciates. This is because reducing prices is more feasible than raising them in the presence of competition. By contrast, in relatively less competitive/segmented markets the pass-through may be higher for depreciations compared to appreciations: importers may fully pass through higher costs to consumers when the local currency depreciates but increase their margins and keep local prices unchanged when the local currency appreciates. The evidence on sign asymmetries is mixed. While Bussiere (2013) for G7 countries and Colavecchio and Rubene (2020) for 19 euro area countries find that the pass-through is higher for exchange rate appreciations, Delatte and Villavicencio (2012) for 4 major developed countries and Caselli and Roitman (2016) for 28 emerging markets find that the pass-through is lower for exchange rate appreciations. Comunale and Simola (2018) for 7 CIS countries find no evidence of sign asymmetries in the pass-through, while Ben Cheikh (2012) for 12 euro area countries finds that the pass-through is higher for exchange rate depreciations in some countries and lower in others.

The exchange rate regime adopted by the monetary authorities could also have implications for the pass-through. On the one hand, a less volatile exchange rate regime is more likely to encourage invoicing in the local currency (local currency pricing) and hence lead to lower pass-through. On the other hand, a shift in the exchange rate peg is likely to be perceived as a permanent shock by businesses and population, resulting in a higher pass-through. Given mixed theoretical predictions, it is not surprising that the empirical evidence is also mixed. Barhoumi (2006) for 24 developing countries, Beirne and Bijsterbosch (2011) for 9 Central and Eastern European countries, Caselli and Roitman (2016) for 28 emerging markets, and Razafimahefa (2012) for Sub-Saharan Africa countries find that the pass-through is higher for flexible exchange rate regimes, while Kohlscheen (2010) for 8 emerging economies finds that the pass-through is lower for flexible exchange rate regimes.

Finally, the pass-through may vary around crisis periods. It is expected that inflation rates would decelerate in the aftermath of the crisis, leading to a lower pass-through in a low 
inflation environment (Taylor, 2000; Choudhri and Hakura, 2006). The empirical evidence supports this hypothesis. Jasova and others (2019) for a sample of 22 emerging economies find that the pass-through has declined following the global financial crisis (after the third quarter of 2009). Similarly, Ito and Saito (2008) found lower pass-through in East Asian countries following the Asian crisis (except for Indonesia).

To sum up, ERPT has been a subject of numerous empirical studies, but to our best knowledge none of them has focused on the CCA countries. The speed of the pass-through tends to be larger in emerging and low-income countries compared to advanced economies. The speed of the pass-through differs widely across country samples and time periods and there is mixed evidence on non-linearities and asymmetries. In what follows, we quantify the pass-through in the CCA countries, test for possible non-linearities and asymmetries, and compare our results with findings in the literature.

\section{DATA ANd Stylized FACTS}

In this section we present the data used in our analysis and some stylized facts. Table 2 presents the variables used in our analysis. We use monthly data for seven CCA countries over the period January 1995-May 2020. The average local currency exchange rate vis-à-vis the US dollar and the CPI index are taken from the IMF's International Financial Statistics. The de-facto exchange rate classification is taken from the IMF's Annual Report of Exchange Rate Arrangements and Exchange Restrictions (AREAER) database. We calculate annual growth rates of exchange rate and CPI index variables by taking year-on-year log differences over the 12-months period.

Figures 1 and 2 present the dynamics of annual CPI inflation and exchange rate changes for the CCA countries over the sample under consideration. They suggest that the panel is not balanced and for some countries the data is not available from the beginning of the sample period. Inflation rates have been very high reaching 40-70 percent in late 1990s, when the CCA countries were in the process of transition from centrally planned to market economies. Over time, inflation rates have decelerated, but some spikes were observed around the global financial crisis (2008-2009). The CCA countries have entered a relatively low inflation environment not exceeding 10 percent per annum in most countries after the global financial crisis. Like inflation, exchange rate depreciations were particularly high in late 1990s. Over time, exchange rate movements have stabilized, but some depreciation spikes were observed around the global financial crisis (2008-2009) and the recent oil price shock (2015).

Figures 3 presents the association between annual exchange rate changes and CPI inflation rates for the sample under consideration. There is a positive relationship between the two, suggesting a positive pass-through on impact.

While the relationship between annual exchange rate changes and CPI inflation rates is positive, it is not clear in which direction the causality runs. To shed light on this question, we have run a Granger-causality test for the CCA panel using 12 lags of variables. The 
results suggest that exchange rate changes Granger-cause CPI inflation ( $p$-value $=0.00$ ), but $\mathrm{CPI}$ inflation does not Granger-cause exchange rate changes $(\mathrm{p}$-value $=0.10)$. Therefore, a univariate econometric model with inflation as a dependent variable and exchange rate changes as an independent variable could be used to estimate the pass-through. Nevertheless, as a robustness check, we also present results from a bi-variate panel VAR model.

\section{EMPIRICAL SPECIFICATION AND ESTIMATIONRESULTS}

In this section, we estimate the speed of ERPT in the CCA countries using the local projections method. We start by presenting results from the linear model, followed by checks for possible non-linearities and asymmetric pass-through.

\section{A. The Linear Model}

We use the linear projections method of Jorda (2005) to assess the speed of ERPT in the CCA countries. The empirical specification takes the following form:

$\Delta l c p i_{i, t+h}-\Delta l c p i_{i, t-1}=\alpha_{i}^{h}+\eta_{t}^{h}+\beta^{h} \Delta l e r_{i, t}+\sum_{k=1}^{12} \rho_{k}^{h} \Delta l c p i_{i, t-k}+\sum_{k=1}^{12} \gamma_{k}^{h} \Delta l e r_{i, t-k}+\varepsilon_{i, t+h}$

where $i$ denote countries, $t$ denotes time, $h=[0,1, \ldots, 12]$ denotes the projection horizon, $\Delta l c p i$ is the annual (year-on-year) logarithmic difference in the CPI index, $\Delta l e r$ is the annual (year-on-year) logarithmic difference in the exchange rate of the national currency vis-à-vis the US dollar, and $\varepsilon$ is the i.i.d. error term. Regressions include country fixed effects $\left(\alpha_{i}\right)$ to control for country-specific unobserved heterogeneity and time fixed effects $\left(\eta_{t}\right)$ to control for common shocks (like changes in oil prices) affecting all CCA countries simultaneously. Twelve lags of dependent and independent variables are included to control for omitted variables and overlapping annual growth rates in the monthly data. We use Driscoll-Kraay standard errors to account for possible serial correlation and cross-sectional dependence in the error terms.

The coefficient of interest is $\beta$, which represents the pass-through for the projection horizon $h$. It is expected to be positive, consistent with the hypothesis that the exchange rate depreciation is associated with an increase in inflation rates.

Figure 4 presents the pass-through over the 12-month projection horizon for the linear model. The inflation rate raises by 0.1 percent in response to a 1 percentage point change in exchange rate depreciation on impact $(E R P T=10$ percent). After 12 months, the passthrough reaches about 25 percent. The pass-through in the CCA countries is somewhat higher than the pass-through in CIS countries (Comunale and Simola, 2018) and 28 emerging economies (Caselli and Roitman, 2016), but it is lower compared to the pass-through in SubSaharan Africa countries (Razafimahefa, 2012). 
As a robustness check, we run a bilateral panel VAR model with country and time fixed effects for CPI inflation and exchange rate changes. The structural shock identification is based on the Choleski factorization, where consistent with the Granger-causality test results exchange rate changes are ordered first. Figure 5 presents the impulse-response function, which suggests that the ERPT from this model is qualitatively similar to the one from the local projections model, supporting the robustness of results. After 12 months, the ERPT reaches 18 percent, which is somewhat lower than the estimate from the local projections model. However, the confidence interval around this estimate overlaps substantially with that from the local projections model, suggesting that the difference between the two estimates is statistically imprecise.

\section{B. Does ERPT Vary with the Size of Exchange Rate Changes?}

In this section we assess whether the response of inflation to exchange rate changes varies with the size of exchange rate changes. We distinguish between periods of large exchange rate movements when annual exchange rate change exceed 15 percent in absolute terms (high appreciation or depreciation), and small movements when annual exchange rate change do not exceed 15 percent in absolute terms. ${ }^{4}$ For that purpose, we create a dummy variable $d 1$ :

$d 1= \begin{cases}1, & \text { if } d \text { ler }>\text { abs }(15) \\ 0, & \text { otherwise (small movements) }\end{cases}$

The empirical specification takes the following form:

$\Delta l c p i_{i, t+h}-\Delta l c p i_{i, t-1}=\alpha_{i}^{h}+\eta_{t}^{h}+\beta_{1}^{h} \Delta l e r_{i, t}+\lambda^{h} d 1+\beta_{2}^{h} d 1 \Delta l e r_{i, t-k}+\sum_{k=1}^{12} \rho_{k}^{h} \Delta l c p i_{i, t-k}+\sum_{k=1}^{12} \gamma_{k}^{h} \Delta l e r_{i, t-k}+\varepsilon_{i, t+h}$

where $\beta_{l}$ represents the pass-through in response to small movements in the exchange rate and $\left(\beta_{1}+\beta_{2}\right)$ represents the pass-through in response to large movements in the exchange rate.

Figure 6 presents the pass-through in response to large and small movements in the exchange rate over the 12-month projection horizon. We do not find evidence of non-linearities or asymmetric response to large and small exchange rate fluctuations. In both cases, the passthrough is about 10 percent on impact and about 30 percent after 12 months. However, the confidence interval around ERPT for large exchange rate fluctuations is somewhat wider compared to that for small exchange rate fluctuations, suggesting that response to large exchange rate fluctuations is more heterogenous in the CCA sample. This result is in contrast with some studies that report size asymmetries for 28 emerging economies (Caselli and

\footnotetext{
${ }^{4}$ We chose the 15 percent threshold for the definition of la rge exchange rate changes since it corresponds to one standard deviation of the annual exchange ra te growth in the total sample. We ha ve also tried 10 percent, 20 percent, and 30 percent thresholds and the results remain qualitatively unchanged.
} 
Roitman, 2016), 7 CIS countries (Comunale and Simola, 2018), and 19 euro area countries (Colavecchio and Rubene, 2020).

\section{Does ERPT Vary with the Sign of Exchange Rate Changes?}

In this section we assess whether the response of inflation to exchange rate changes is different for ex change rate appreciations versus depreciations. For that purpose, we create a dummy variable $d 2$ :

$d 2= \begin{cases}1, & \text { if } \text { dler }>0 \\ 0, & \text { otherwise }\end{cases}$

The empirical specification takes the following form:

$\Delta l c p i_{i, t+h}-\Delta l c p i_{i, t-1}=\alpha_{i}^{h}+\eta_{t}^{h}+\gamma_{1}^{h} \Delta l e r_{i, t}+\lambda^{h} d 2+\gamma_{2}^{h} d 2 \Delta l e r_{i, t-k}+\sum_{k=1}^{12} \rho_{k}^{h} \Delta l c p i_{i, t-k}+\sum_{k=1}^{12} \gamma_{k}^{h} \Delta l e r_{i, t-k}+\varepsilon_{i, t+h}$

where $\gamma_{1}$ represents the pass-through in response to exchange rate appreciations and $\left(\gamma_{1}+\gamma_{2}\right)$ represents the pass-through in response to exchange rate depreciations.

Figure 7 presents the pass-through in response to exchange rate appreciations and depreciations over the 12-month projection horizon. We do not find significant evidence of asymmetric response to the sign of exchange rate fluctuations. In both cases, the passthrough is about 10 percent on impact. While the pass-through for appreciations is about 10 percent higher than that for depreciations after 12 months, this difference is not statistically significant given the wide confidence intervals. This result is consistent with the evidence for 7 CIS countries in Comunale and Simola (2018).

\section{Does ERPT Vary with Exchange Rate Regimes?}

In this section we assess whether the response of inflation to exchange rate changes varies for different exchange rate regimes. Using the IMF's de-facto classification of exchange rate regimes, we create a dummy variable $d 3$ as follows:

$d 3= \begin{cases}1, & \text { if free floating or managed floating with no pre }- \text { determined path } \\ 0, & \text { otherwise (pegs, crawling bands, stabilized arrangements) }\end{cases}$

The empirical specification takes the following form:

$\Delta l c p i_{i, t+h}-\Delta l c p i_{i, t-1}=\alpha_{i}^{h}+\eta_{t}^{h}+\lambda_{1}^{h} \Delta l e r_{i, t}+\lambda^{h} d 3+\lambda_{2}^{h} d 3 \Delta l e r_{i, t-k}+\sum_{k=1}^{12} \rho_{k}^{h} \Delta l c p i_{i, t-k}+\sum_{k=1}^{12} \gamma_{k}^{h} \Delta l e r_{i, t-k}+\varepsilon_{i, t+h}$

where $\lambda_{1}$ represents the pass-through in periods of fixed exchange rate regimes and $\left(\lambda_{1}+\lambda_{2}\right)$ represents the pass-through in response to floating exchange rate regimes.

Figure 8 presents the pass-through in different exchange rate regime periods over the 12month projection horizon. We do not find significant evidence of asymmetric ERPT in fixed 
versus floating exchange rate regimes. In both cases, the pass-through is about 10 percent on impact and about 25 percent after 12 months. This result is in contrast with evidence from other emerging and low-income countries, where the pass-through was found to be lower in flexible exchange rate regimes (Barhoumi, 2006; Beirne and Bijsterbosch, 201 1; Caselli and Roitman, 2016; Razafimahefa, 2012).

\section{E. Does the ERPT Differ Across Energy-Exporters and Energy-Importers?}

In this section we assess whether the response of inflation to exchange rate changes differs across energy-exporting and energy-importing countries. For that purpose, we create a dummy variable $d 4$ as follows:

$d 4= \begin{cases}1, & \text { for energy }- \text { importing CCA countries (ARM, GEO, KGZ, TJK) } \\ 0, & \text { for energy }- \text { exporting CCA countries (AZE, KAZ, UZB) }\end{cases}$

The empirical specification takes the following form:

$\Delta l c p i_{i, t+h}-\Delta l c p i_{i, t-1}=\alpha_{i}^{h}+\eta_{t}^{h}+\xi_{1}^{h} \Delta l e r_{i, t}+\lambda^{h} d 4+\xi_{2}^{h} d 4 \Delta l e r_{i, t-k}+\sum_{k=1}^{12} \rho_{k}^{h} \Delta l c p i_{i, t-k}+\sum_{k=1}^{12} \gamma_{k}^{h} \Delta l e r_{i, t-k}+\varepsilon_{i, t+h}$

where $\xi_{1}$ represents the pass-through in energy-exporting CCA countries and $\left(\xi_{1}+\xi_{2}\right)$ represents the pass-through in energy-importing CCA countries.

Figure 9 presents the pass-through for energy exporters and energy importers over the 12month projection horizon. We find that the pass-through is lower in energy-exporting countries by about 2 percentage points on impact and about 5 percentage points after 12 months, and this difference is significant at the 90 percent confidence level for the first four months of the projection horizon. This result could be explained by structural differences across these groups of countries (economic diversification, reliance on remittances, proportion of imported goods in CPI baskets).

\section{F. Has ERPT Changed in the Post-Global Financial Crisis Period?}

In this section we assess whether the response of inflation to exchange rate changes has changed after the global financial crisis. For that purpose, we create a dummy variable $d 4$ as follows:

$d 5= \begin{cases}1, & \text { for September } 2008-\text { May } 2020 \\ 0, & \text { otherwise }\end{cases}$

The empirical specification takes the following form:

$\Delta l c p i_{i, t+h}-\Delta l c p i_{i, t-1}=\alpha_{i}^{h}+\eta_{t}^{h}+\rho_{1}^{h} \Delta l e r_{i, t}+\lambda^{h} d 5+\rho_{2}^{h} d 5 \Delta l e r_{i, t-k}+\sum_{k=1}^{12} \rho_{k}^{h} \Delta l c p i_{i, t-k}+\sum_{k=1}^{12} \gamma_{k}^{h} \Delta l e r_{i, t-k}+\varepsilon_{i, t+h}$

where $\rho_{I}$ represents the pass-through in the pre-crisis period and $\left(\rho_{1}+\rho_{2}\right)$ represents the passthrough in the post-crisis period. 
Figure 10 presents the pass-through in pre- and post-crisis periods over the 12-month projection horizon. We find evidence of asymmetric ERPT in these periods. The passthrough is lower in the post-crisis period relative to the pre-crisis period by about 5 percentage points on impact and about 15 percentage points after 12 months, and this difference is significant at the 90 percent confidence level. This result is consistent with Ito and Saito (2008) and Jasova and others (2019), who also find lower pass-through in emerging economies in the aftermath of the Asian crisis and the global financial crisis, respectively. The decline in inflation in the post-crisis period was driven by both external (global slowdown in inflation) and domestic (improved monetary policy frameworks and transition to inflation targeting) structural factors, supporting lower ERPT.

\section{Conclusions}

The extent and speed of ERPT has been at the center of policy discussions in many countries. A large empirical literature has estimated the pass-through for different country groups and sample periods, but none of the studies has focused on the CCA region.

This study fills this gap and estimates the pass-through for the CCA countries using monthly data for the January 2015-May 2020 period. The estimations are performed using the univariate local projections method, since the Grange-causality tests suggest that causality runs from exchange rate changes to inflation, and not vice versa. As a robustness check, we also run a panel VAR model.

The results could be summarized as follows (Table 3 ). The average ERPT in the CCA countries is estimated at about 10 percent on impact and about 25 percent after 12 months. The pass-through in the CCA countries is somewhat higher than the pass-through in CIS countries (Comunale and Simola, 2018) and 28 emerging economies (Caselli and Roitman, 2016), but it is lower compared to the pass-through in Sub-Saharan Africa countries (Razafimahefa, 2012).

We find no evidence of asymmetric ERPT with respect to the size and the sign of exchange rate changes. Also, the pass-through is broadly unchanged in fixed versus floating exchange rate regimes. The pass-through has been $5-15$ percentage points lower in the post-crisis period and this lower ERPT is more relevant for the current period characterized by a relatively low inflation environment observed in many CCA countries recently.

These results have important policy implications. The speed of the pass-through and the absence of non-linearities with respect to the size and sign of exchange rate changes could be used by the monetary authorities for inflation projections. The absence of non-linearities in the pass-through with respect to the exchange rate regime suggests that transition from fixed to floating exchange rate regimes (including inflation targeting) would not impose additional inflationary costs. Finally, the decline in the pass-through following the global financial crisis provides yet additional indication on the benefits of maintaining a low inflation environment. 
Figure 1. Dynamics of CPI Inflation in the CCA Countries

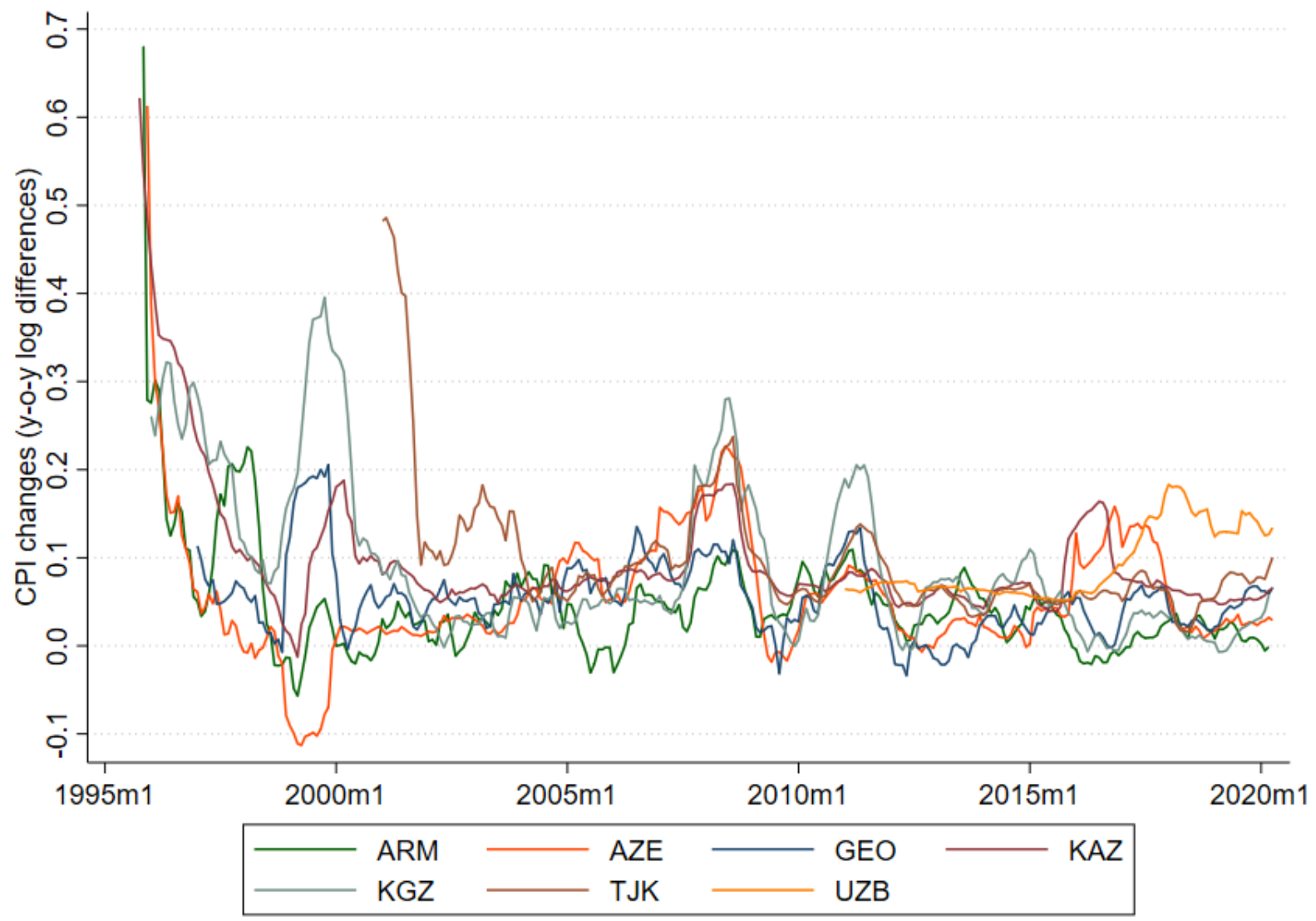

Source: International Fina ncial Sta tistics a nd IMF Staff estimations. 
Figure 2. Dynamics of Exchange Rate Changes in the CCA Countries

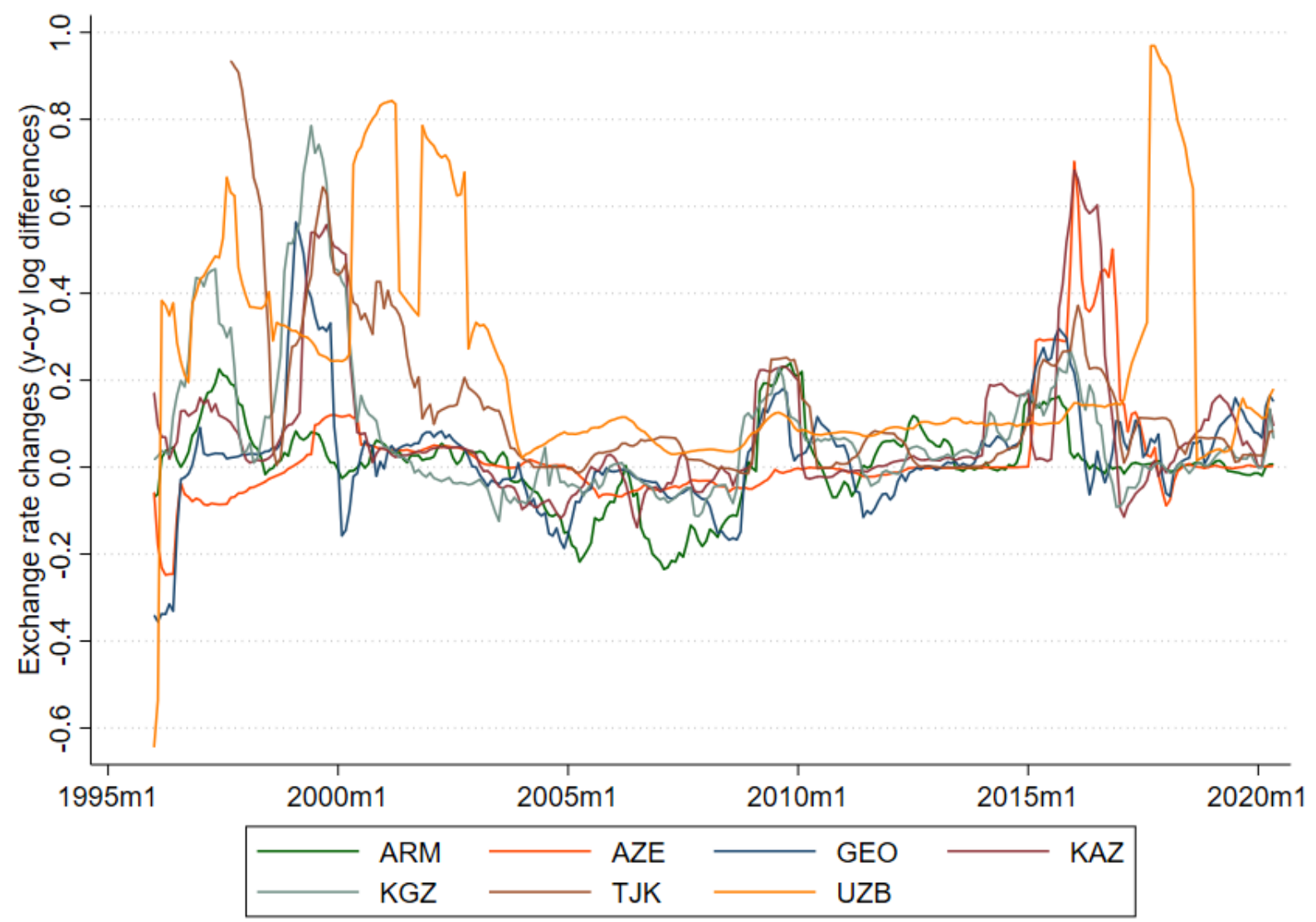

Source: International Fina ncial Sta tistics and IMF Staff estimations.

Note: Positive numbers indicate depreciation of the local currency vis-à-vis the US dollar. 
Figure 3. Association Between CPI Inflation and Exchange Rate Changes in the CCA Countries

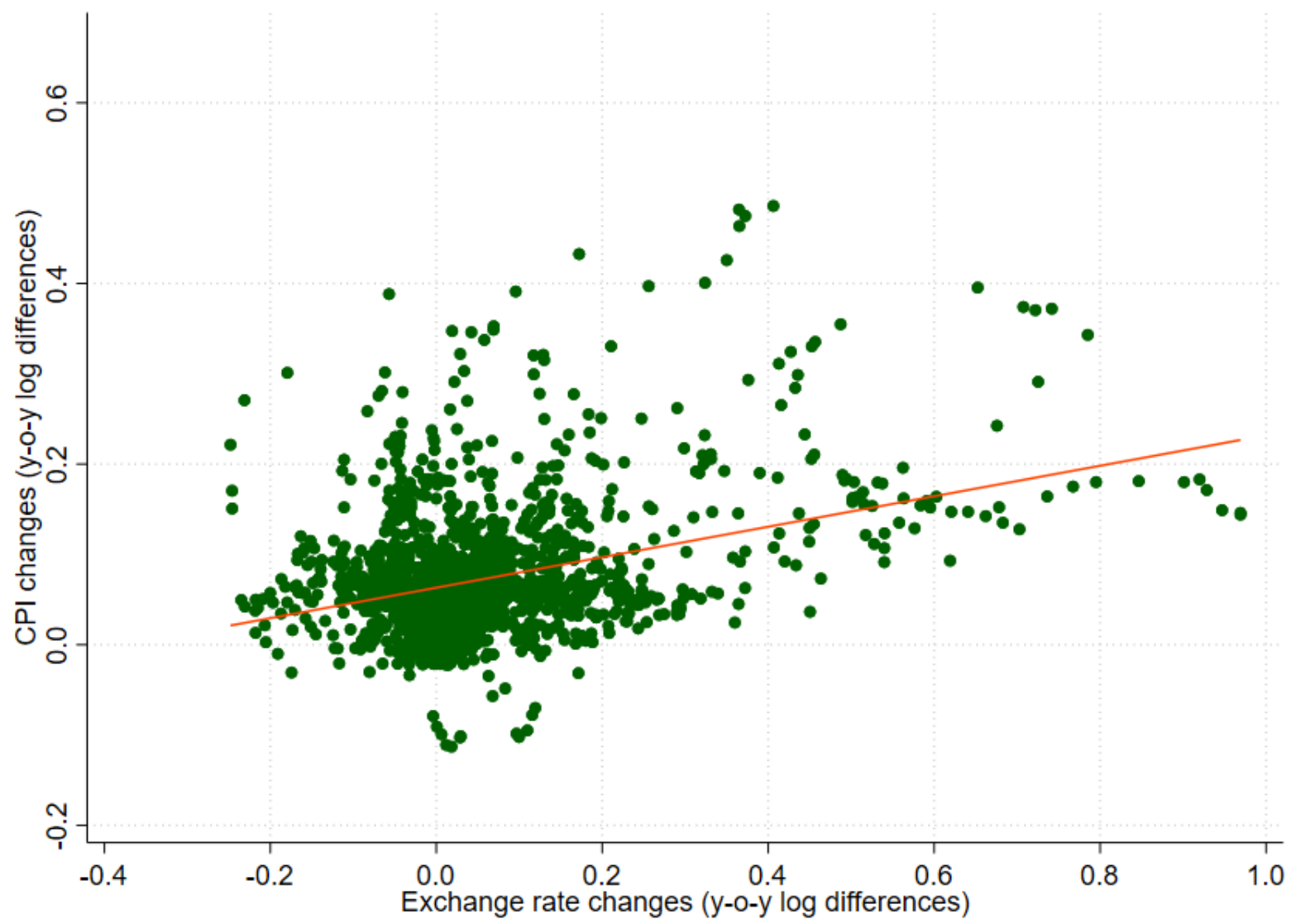

Source: International Fina ncial Sta tistics a nd IMF Staff estimations. 
Figure 4. ERPT: The Linear Model

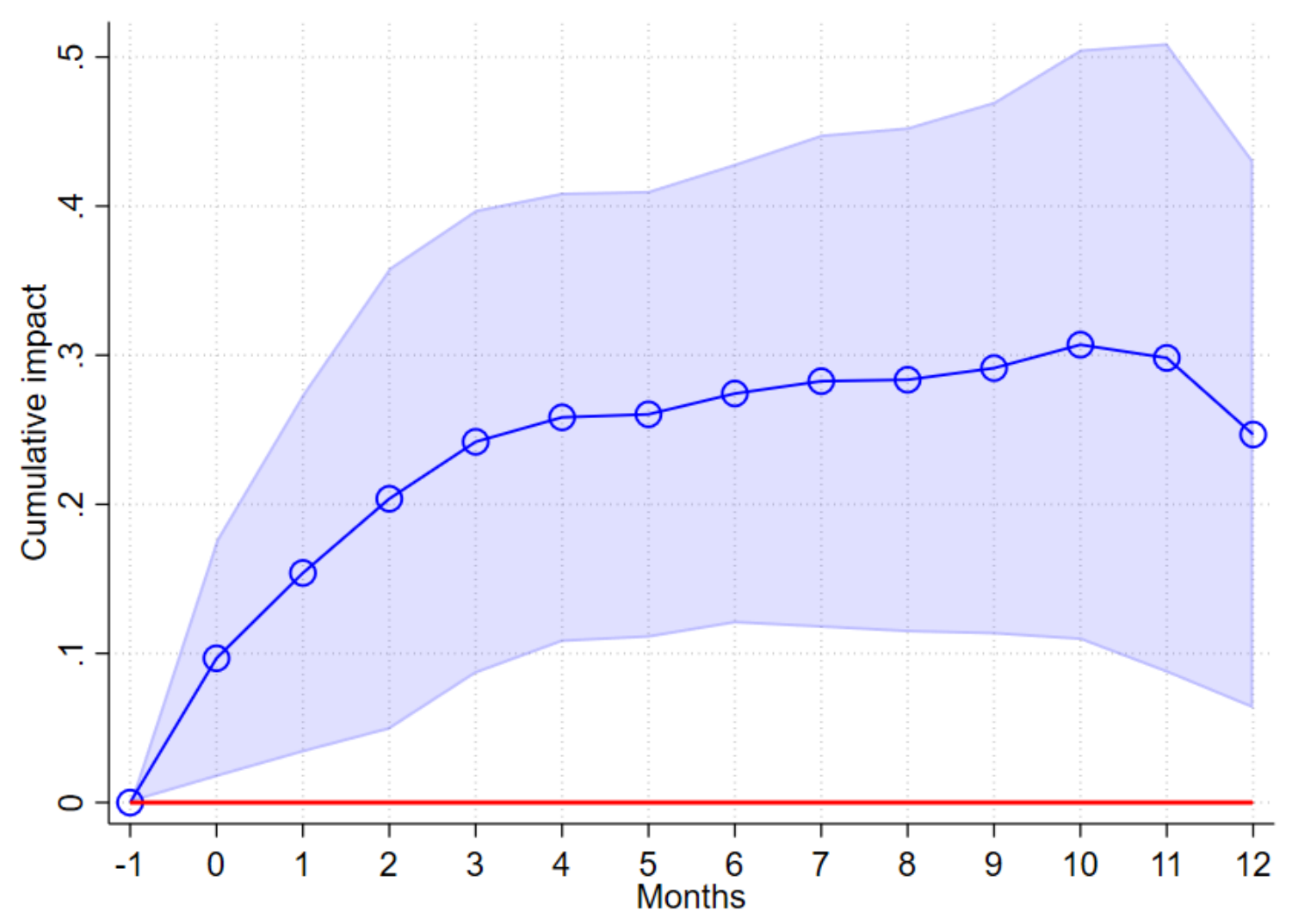

Source: International Fina ncial Sta tistics a nd IMF Staff estimations.

Note: Reported is the percentage response of a nnualCPI inflation to a 1 percent depreciation of national currency vis-à-vis the US dollar in period 0 and the 90 percent confidence interval. Estimations are performed for Armenia, Azerbaijan, Georgia, Ka zakhstan, Kyrgyz Republic, Tajikistan, and Uzbekistan over theperiod January 1995-May 2020. 
Figure 5. ERPT: The Panel VAR Model

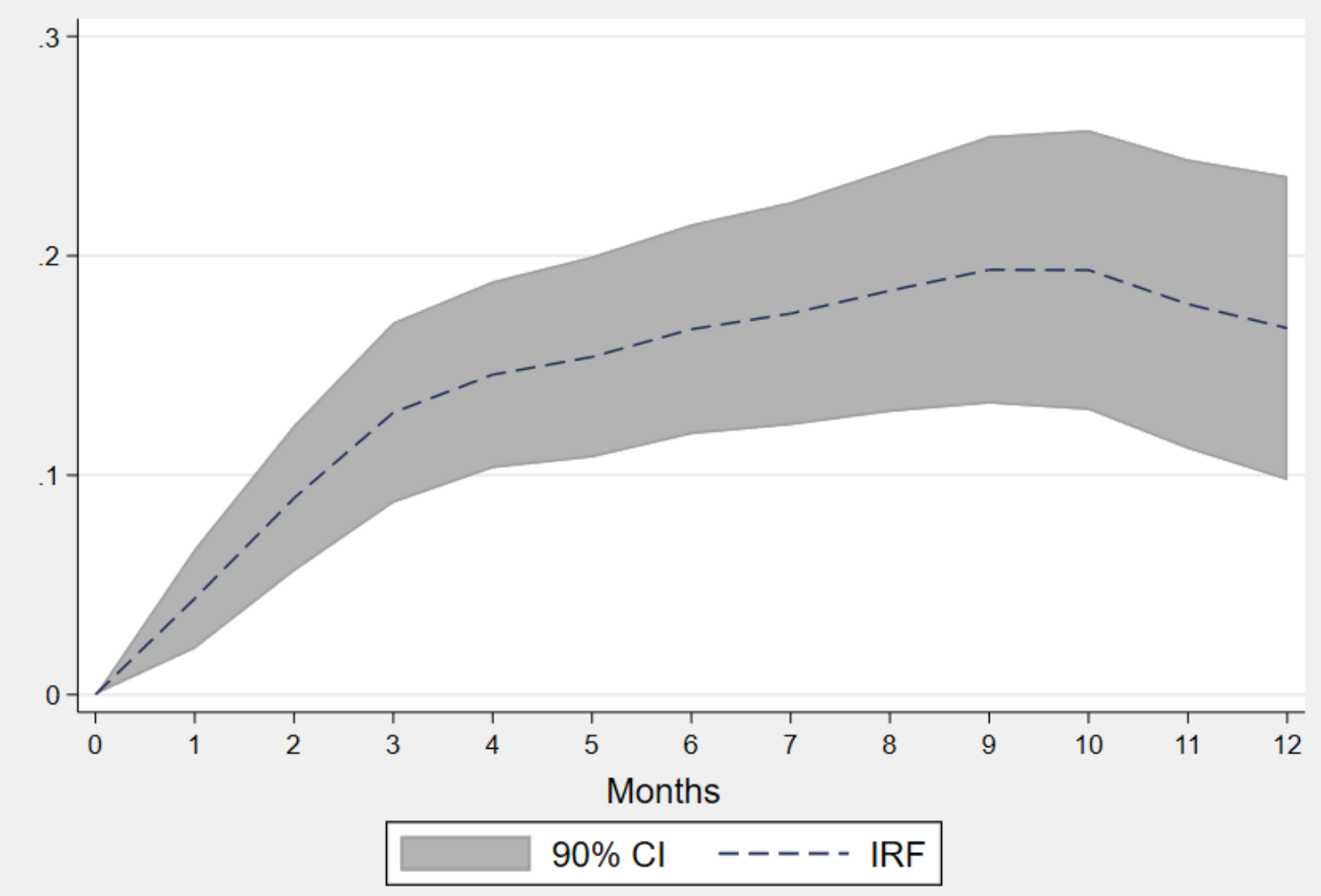

impulse : response

Source: International Fina ncial Sta tistics a nd IMF Staffestimations.

Note: Reported is the percentage response of a nnualCPI inflation to a 1 percent depreciation of national currency vis-à-vis theUS dollar in period 1 and the 90 percent confidence interval. Estimations are performed using the panel VAR model with country-specific fix ed effects and time effects for Armenia, Azerbaijan, Georgia, Kazakhstan, Kyrgyz Republic, Tajikistan, and Uzbekistan over the period January 1995-May 2020. 
Figure 6. ERPT: Non-Linearities for the Size of Exchange Rate Depreciation

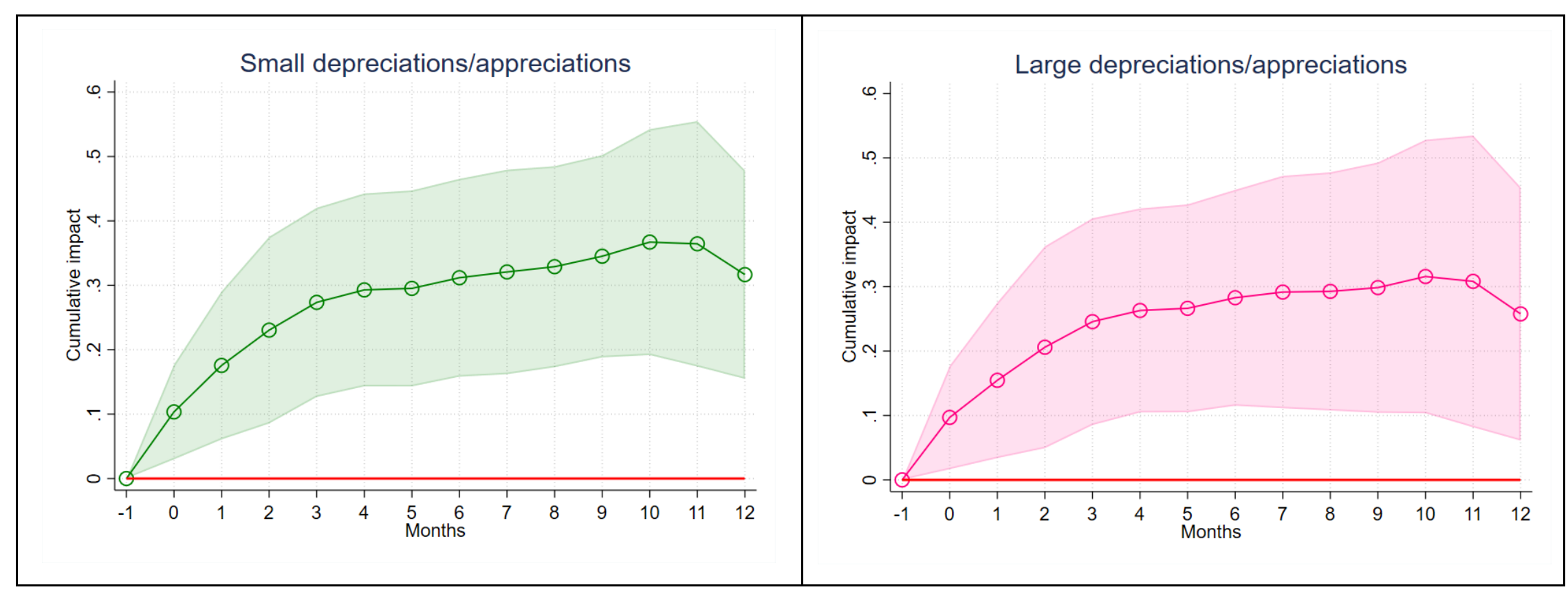

Source: International Fina ncial Sta tistics a nd IMF Staff estimations.

Note: Reported is the percentage response of annualCPI inflation to a 1 percent depreciation of national currency vis-à-vis the US dolla rin period 0 and the 90 percent confidence interval. Large depreciations (appreciations) are defined a s those in excess of 15 percent per a nnum. Estimations are performed for Armenia, Azerbaijan, Georgia, Ka zakhstan, Kyrgyz Republic, Tajikistan, and Uzbekistan over the period January 1995-May 2020. 
Figure 7. ERPT: Non-Linearities for Exchange Rate Appreciation versus Depreciation

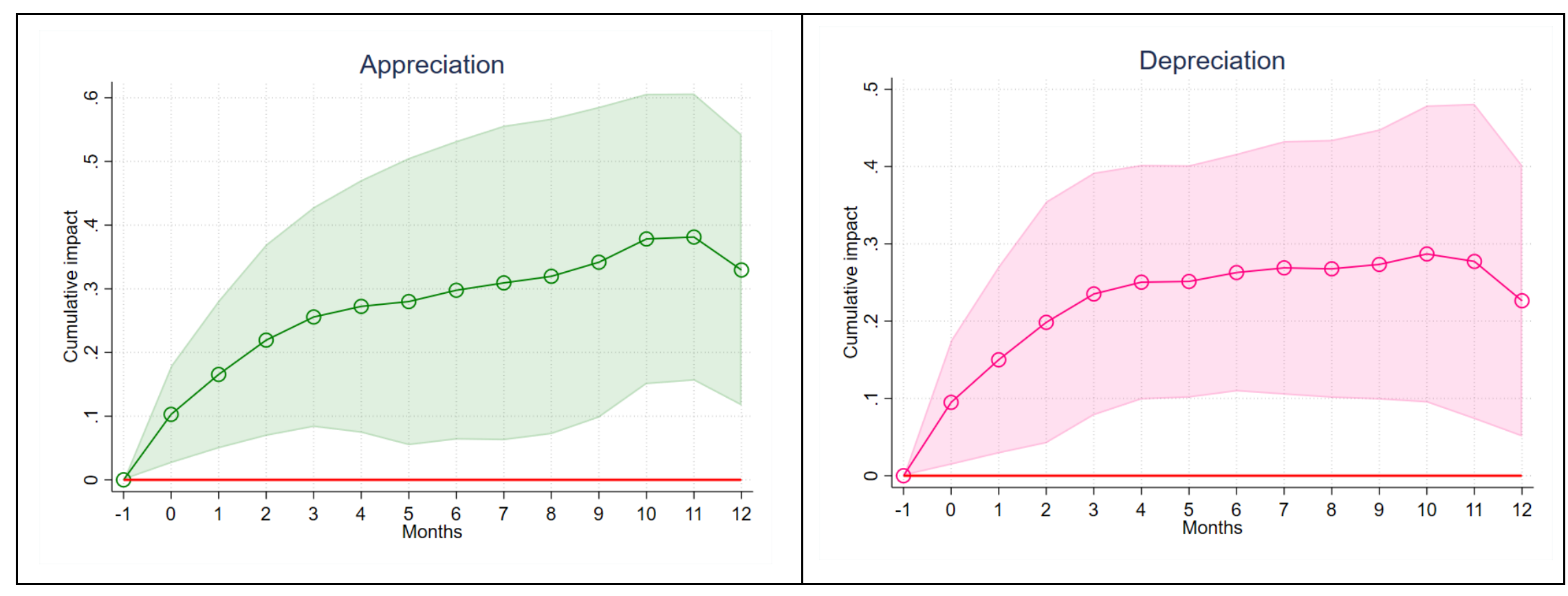

Source: International Fina ncial Statistics a nd IMF Staff estimations.

Note: Reported is the percentage response of annualCPI inflation to a 1 percent depreciation of national currency vis-à-vis the US dollar in period 0 and the 90 percent confidence interval. Estimations are performed for Armenia, Azerbaijan, Georgia, Kazakhstan, KyrgyzRepublic, Tajikistan, a nd Uzbekistan over the period January 1995-May 2020. 
Figure 8. ERPT: Non-Linearities for Exchange Rate Regimes

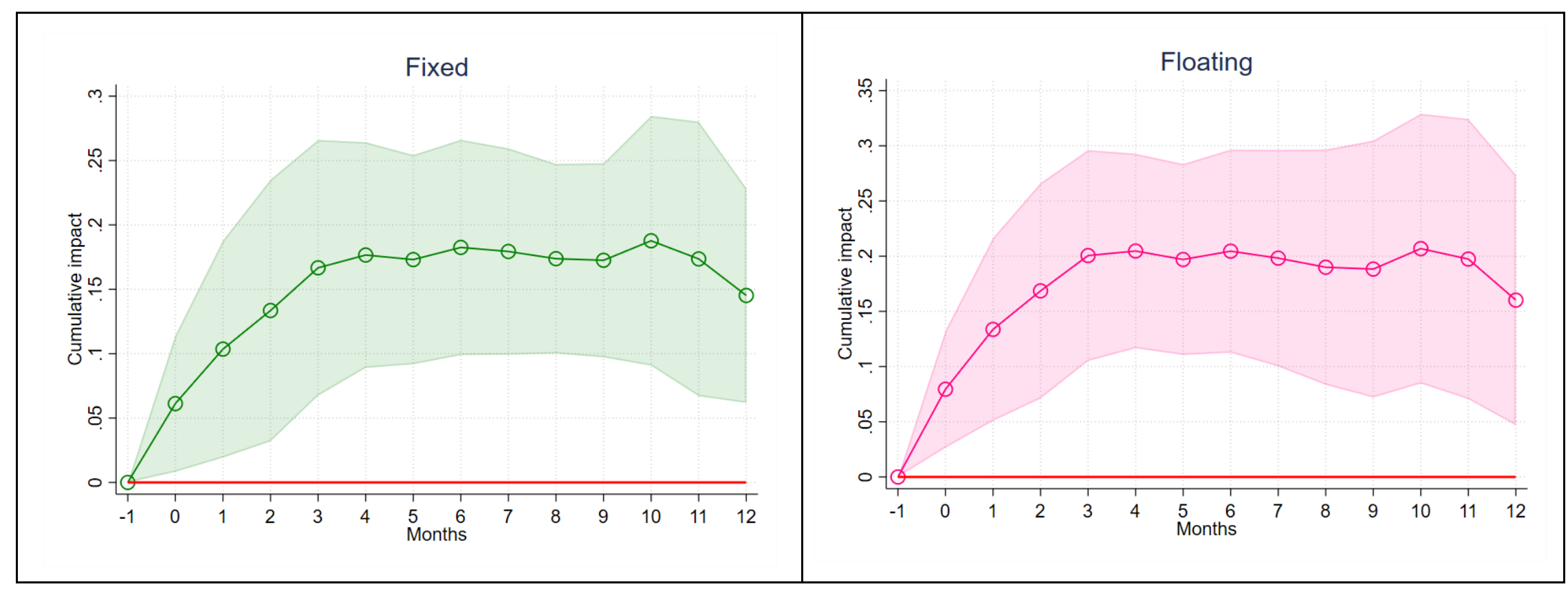

Source: International Fina ncial Sta tistics and IMF Staffestimations.

Note: Reported is the percentage response of annualCPI inflation to a 1 percent depreciation of national currency vis-à-vis the US dollar in period 0 and the 90 percent confidence interval. Estimations are performed for Armenia, Azerbaijan, Georgia, Kazakhstan, KyrgyzRepublic, Tajikistan, and Uzbekistan over the period Ja nuary 1995-May 2020.

Exchange rate regimes a retaken from IMF's de-facto classification for the period 2000-2020: fixed refers to various pegged regimes, crawling bands, a nd stabilized arrangements, while floating refers to the freely and managed floating regimes. 


\section{Figure 9. ERPT: Differences Between Energy-Exporting and Energy-Importing Countries}

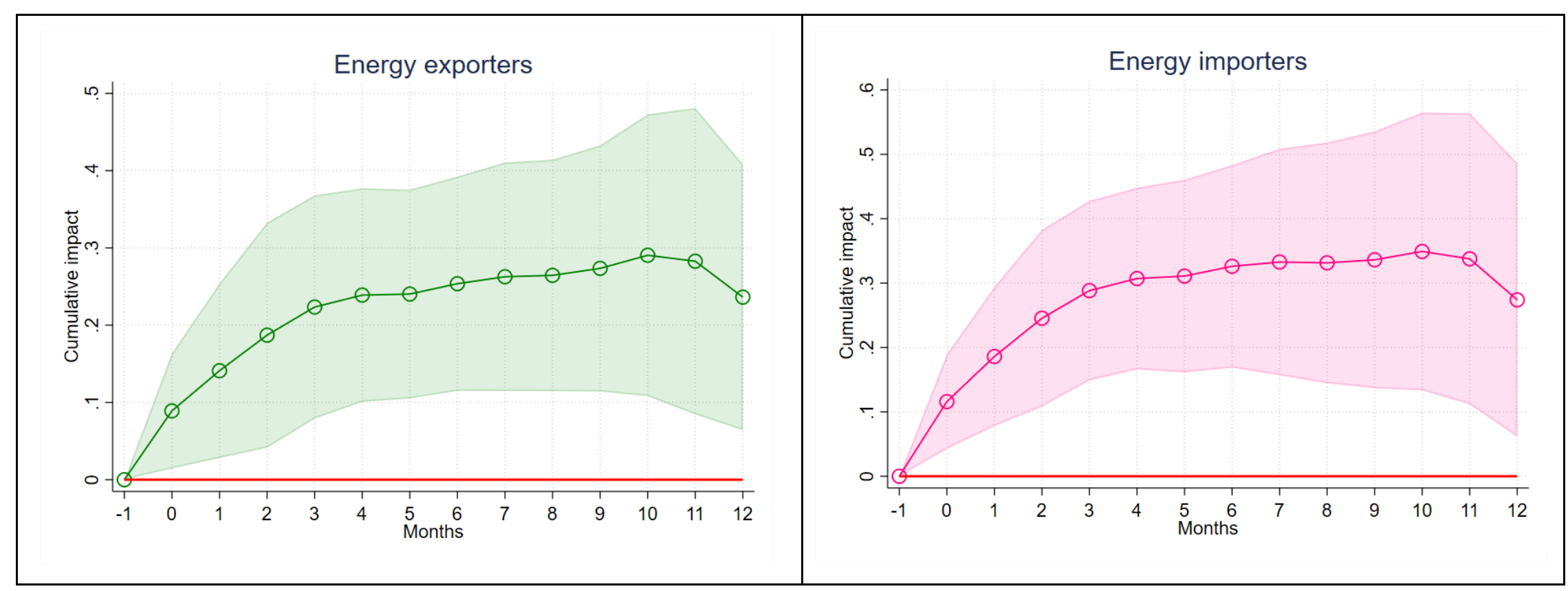

Source: International Fina ncial Statistics and IMF Staffestimations.

Note: Reported is the percentage response of annualCPI inflation to a 1 percent depreciation of national currency vis-à-vis the US dolla rin period 0 and the 90 percent confidence interval. Estimations are performed for energy-exporting (Azerbaijan, Ka zakhstan, Uzbekistan) and energy-importing (Armenia, Georgia, Kyrgyz Republic, Tajikistan) CCA countries over the period January 1995-May 2020. 


\section{Figure 10. ERPT: Non-Linearities for Pre-Crisis and Post-Crisis Periods}

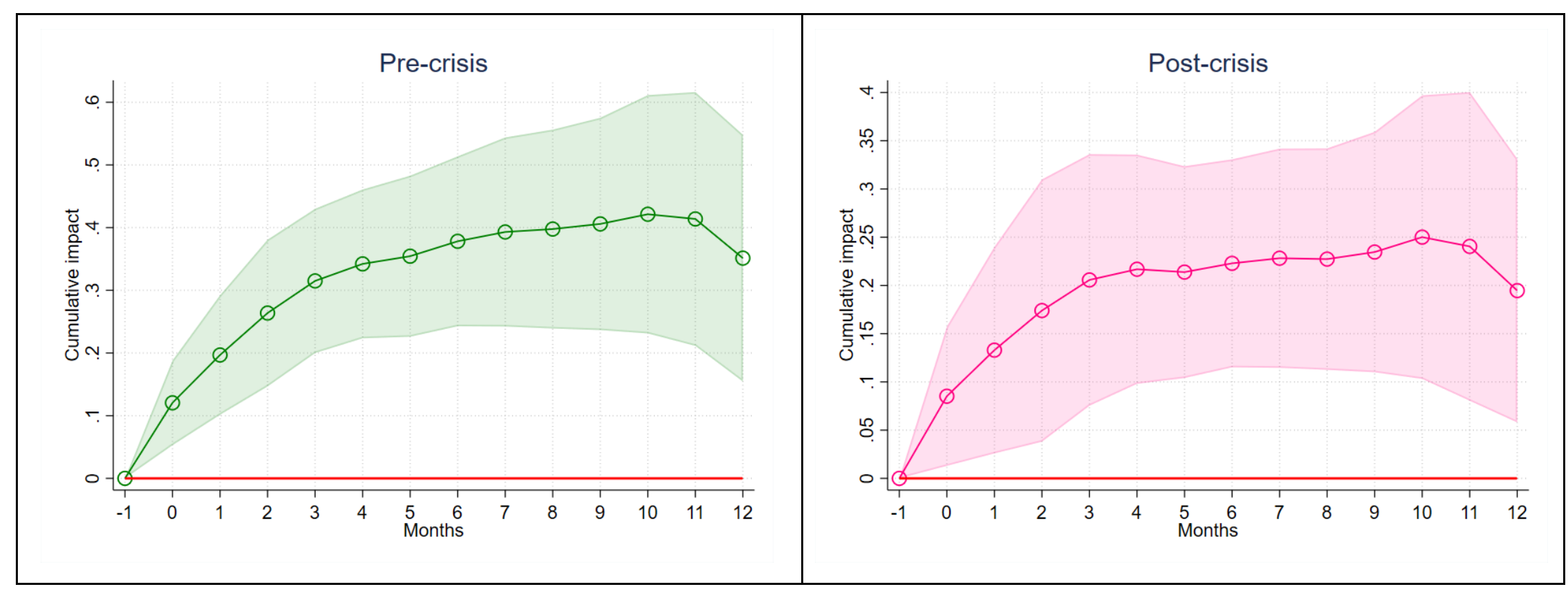

Source: International Fina ncial Statistics and IMF Staffestimations.

Note: Reported is the percentage response of annualCPI inflation to a 1 percent depreciation of national currency vis-à-vis the US dolla rin period 0 and the 90 percent confidence interval. Estimations are performed for Armenia, Azerbaijan, Georgia, Kazakhstan, KyrgyzRepublic, Tajikistan, a nd Uzbekistan over the period Ja nuary 1995-May 2020.

The post-crisis period starts from September 2008. 


\section{Table 1. Summary of Selected Exchange Rate Pass-Through Studies}

\begin{tabular}{|c|c|c|c|c|c|c|c|}
\hline \multirow[t]{2}{*}{ Study } & \multirow[t]{2}{*}{ Sample } & \multirow[t]{2}{*}{ Methodology } & \multirow[t]{2}{*}{ Exchange rate pass- } & \multicolumn{4}{|c|}{ Non-linearities/Asymmetric pass-through } \\
\hline & & & & $\begin{array}{l}\text { 1. Size of exchange rate } \\
\text { movements (large vs. } \\
\text { normal movements) }\end{array}$ & $\begin{array}{l}\text { 2. Sign of exchange rate } \\
\text { movements (appreciations } \\
\text { vs. depreciations) }\end{array}$ & $\begin{array}{l}\text { 3. Exchange rate regime } \\
\text { (managed vs. flexible) }\end{array}$ & $\begin{array}{l}\text { 4. Crisis impact (pre- } \\
\text { crisis vs. post-crisis) }\end{array}$ \\
\hline Barhoumi (2006) & $\begin{array}{l}24 \text { developing } \\
\text { countries, 1980- } \\
2003(\mathrm{~A}) \text {. }\end{array}$ & $\begin{array}{l}\text { Pooled Mean } \\
\text { Group (PMG) } \\
\text { estimator. }\end{array}$ & $\begin{array}{l}\text { ERPT }=0.77-0.82 \text { on } \\
\text { average in the long-run. }\end{array}$ & & & $\begin{array}{l}\text { Lower ERPT for flexible } \\
\text { regimes. }\end{array}$ & \\
\hline $\begin{array}{l}\text { Beirne and } \\
\text { Bijsterbosch } \\
(2011)\end{array}$ & $\begin{array}{l}9 \text { Central and Eastern } \\
\text { European countries, } \\
\text { 1995-2008(Q). }\end{array}$ & $\begin{array}{l}\text { Cointegrated } \\
\text { Vector } \\
\text { Autoregression } \\
\text { (CVAR). }\end{array}$ & $\begin{array}{l}\text { ERPT }=0.5-0.6 \text { on } \\
\text { average in the long-run. }\end{array}$ & & & $\begin{array}{l}\text { Lower ERPT for flexible } \\
\text { regimes. }\end{array}$ & \\
\hline $\begin{array}{l}\text { Ben Cheikh } \\
(2012)\end{array}$ & $\begin{array}{l}12 \text { euro area } \\
\text { countries, 1975- } \\
2010(Q) .\end{array}$ & $\begin{array}{l}\text { Logistic Smooth } \\
\text { Transition Model }\end{array}$ & $\begin{array}{l}\text { ERPT }=0.04-0.19 \\
\text { (depending on a } \\
\text { country) in the short- } \\
\text { run. }\end{array}$ & $\begin{array}{l}\text { Higher ERPT for larger } \\
\text { ER changes (threshold is } \\
\text { estimated). }\end{array}$ & $\begin{array}{l}\text { Mixed evidence: for some } \\
\text { countries higher ERPT for } \\
\text { larger ER appreciations, the } \\
\text { opposite holds for others. }\end{array}$ & & \\
\hline Bussiere (2013) & $\begin{array}{l}\text { G7 countries, 1980- } \\
2006(Q) \text {. }\end{array}$ & Panel OLS. & $\begin{array}{l}\text { ERPT }=0.27 \text { for export } \\
\text { prices and } 0.55 \text { for } \\
\text { import prices in the long- } \\
\text { run. }\end{array}$ & $\begin{array}{l}\text { Lower ERPT for larger } \\
\text { ER depreciations (import } \\
\text { prices). }\end{array}$ & $\begin{array}{l}\text { Higher ERPT for } \\
\text { appreciations (export and } \\
\text { import prices). }\end{array}$ & & \\
\hline $\begin{array}{l}\text { Caselli and } \\
\text { Roitman (2016) }\end{array}$ & $\begin{array}{l}28 \text { emerging markets, } \\
1991-2014(\mathrm{M}) .\end{array}$ & Local projections. & $\mathrm{ERPT}=0.2$ after 2 years. & $\begin{array}{l}\text { Higher ERPT for larger } \\
\text { ER depreciations ( } 10 \text { or } \\
20 \text { percent). }\end{array}$ & $\begin{array}{l}\text { Lower ERPT for } \\
\text { appreciations. }\end{array}$ & $\begin{array}{l}\text { Lower ERPT for flexible } \\
\text { regimes (under IT). }\end{array}$ & \\
\hline $\begin{array}{l}\text { Colavecchio and } \\
\text { Rubene (2020) }\end{array}$ & $\begin{array}{l}19 \text { euro area } \\
\text { countries, 1997- } \\
2019(Q) .\end{array}$ & Local projections. & $\begin{array}{l}\text { ERPT }=0.04 \text { after } 2 \\
\text { years. }\end{array}$ & $\begin{array}{l}\text { Higher ERPT for larger } \\
\text { ER depreciations ( } 2.3 \\
\text { percent). }\end{array}$ & $\begin{array}{l}\text { Higher ERPT for } \\
\text { appreciations. }\end{array}$ & & \\
\hline
\end{tabular}

Note: $\mathrm{M}=$ monthly, $\mathrm{Q}=$ quarterly, $\mathrm{A}=$ a nnual, $\mathrm{ERPT}=$ exchange ra te pass-through, $\mathrm{ER}=$ exchange rate, $\mathrm{IT}=$ infla tion targeting, $\mathrm{EM}=\mathrm{emergin}$ markets, $\mathrm{AE}$ advanced economies. 


\section{Table 1 (cont-ed). Summary of Selected Exchange Rate Pass-Through Studies}

\begin{tabular}{|c|c|c|c|c|c|c|c|}
\hline \multirow[t]{2}{*}{ Study } & \multirow[t]{2}{*}{ Sample } & \multirow[t]{2}{*}{ Methodology } & \multirow[t]{2}{*}{ Exchange rate pass- } & \multicolumn{4}{|c|}{ Non-linearities/Asymmetric pass-through } \\
\hline & & & & $\begin{array}{l}\text { 1. Size of exchange rate } \\
\text { movements (large vs. } \\
\text { normal movements) }\end{array}$ & $\begin{array}{l}\text { 2. Sign of exchange rate } \\
\text { movements (appreciations } \\
\text { vs. depreciations) }\end{array}$ & $\begin{array}{l}\text { 3. Exchange rate regime } \\
\text { (managed vs. flexible) }\end{array}$ & $\begin{array}{l}\text { 4. Crisis impact (pre- } \\
\text { crisis vs. post-crisis) }\end{array}$ \\
\hline $\begin{array}{l}\text { Comunale and } \\
\text { Simola (2018) }\end{array}$ & $\begin{array}{l}7 \text { Commonwealth of } \\
\text { Independent States } \\
\text { countries, 1999- } \\
2014(Q) \text {. }\end{array}$ & $\begin{array}{l}\text { Panel OLS, with } \\
\text { fixed effects and } \\
\text { common factors. }\end{array}$ & $\begin{array}{l}\text { ERPT }=0.12-0.13 \text { after } 1 \\
\text { year. }\end{array}$ & $\begin{array}{l}\text { Higher ERPT for larger } \\
\text { ER depreciations ( } 2 \\
\text { percent). }\end{array}$ & $\begin{array}{l}\text { No evidence for } \\
\text { asymmetric sign effects. }\end{array}$ & & \\
\hline $\begin{array}{l}\text { Delatte and } \\
\text { Villavicencio } \\
(2012)\end{array}$ & $\begin{array}{l}4 \text { major developed } \\
\text { countries, 1980- } \\
2009(Q) .\end{array}$ & $\begin{array}{l}\text { Autoregressive } \\
\text { Distributed Lag } \\
\text { Model (ARDL) }\end{array}$ & $\begin{array}{l}\text { ERPT }=0.07-0.46 \\
\text { (depending on a } \\
\text { country) in the long-run. }\end{array}$ & & $\begin{array}{l}\text { Higher ERPT for } \\
\text { depreciations. }\end{array}$ & & \\
\hline $\begin{array}{l}\text { Ito and Saito } \\
\text { (2008) }\end{array}$ & $\begin{array}{l}5 \text { East Asian } \\
\text { countries, 1994- } \\
\text { 2006(M). }\end{array}$ & $\begin{array}{l}\text { Vector } \\
\text { Autoregression } \\
\text { (VAR). }\end{array}$ & $\begin{array}{l}\text { ERPT }=0.03-0.41 \\
\text { (depending on a } \\
\text { country) after } 2 \text { years. }\end{array}$ & & & & $\begin{array}{l}\text { Lower ERPT (except } \\
\text { Indonesia) after the } \\
\text { Asian crisis. }\end{array}$ \\
\hline $\begin{array}{l}\text { Jasova and others } \\
\text { (2019) }\end{array}$ & $\begin{array}{l}22 \text { EMs and } 11 \text { AEs, } \\
\text { 1994-2017(Q). }\end{array}$ & $\begin{array}{l}\text { Panel OLS with } \\
\text { fixed effects. }\end{array}$ & $\begin{array}{l}\text { ERPT is lower in AEs } \\
\text { compared to EMs, } \\
\text { ERPT has been } \\
\text { declining in EMs over } \\
\text { time. }\end{array}$ & $\begin{array}{l}\text { Higher ERPT for larger } \\
\text { ER depreciations. }\end{array}$ & & & $\begin{array}{l}\text { Lower ERPT for post- } \\
\text { crisis period (starting } \\
\text { from 2009Q3). }\end{array}$ \\
\hline Kilic (2016) & $\begin{array}{l}6 \text { OECD countries, } \\
1975-2010(Q)\end{array}$ & $\begin{array}{l}\text { Logistic Smooth } \\
\text { Transition Model }\end{array}$ & $\begin{array}{l}E R P T=0.42-0.91 \text { for } \\
\text { import prices } \\
\text { (depending on a } \\
\text { country) in the long-run. }\end{array}$ & $\begin{array}{l}\text { Higher ERPT for larger } \\
\text { ER appreciations } \\
\text { (threshold is estimated). }\end{array}$ & & & \\
\hline Kohlscheen (2010) & $\begin{array}{l}8 \text { emerging } \\
\text { economies, 1995- } \\
2008(M) \text {. }\end{array}$ & $\begin{array}{l}\text { Vector } \\
\text { Autoregression } \\
\text { (VAR). }\end{array}$ & $\begin{array}{l}\text { ERPT }=0.09-0.59 \\
\text { (depending on a } \\
\text { country) after } 1 \text { year. }\end{array}$ & & & $\begin{array}{l}\text { Higher ERPT for } \\
\text { flexible regimes. }\end{array}$ & \\
\hline $\begin{array}{l}\text { Razafimahefa } \\
(2012)\end{array}$ & $\begin{array}{l}\text { Sub-Saharan Africa } \\
\text { region, 1985- } \\
\text { 2008(Q). }\end{array}$ & & $\begin{array}{l}\text { ERPT }=0.4 \text { (on average) } \\
\text { after } 1 \text { year. }\end{array}$ & & & $\begin{array}{l}\text { Lower ERPT for flexible } \\
\text { regimes. }\end{array}$ & \\
\hline
\end{tabular}

Note: $\mathrm{M}=$ monthly, $\mathrm{Q}=$ quarterly, $\mathrm{A}=\mathrm{a}$ nnual, $\mathrm{ERPT}=$ exchange ra te pass-through, $\mathrm{ER}=$ exchange rate, $\mathrm{IT}=$ infla tion targeting, $\mathrm{EM}=\mathrm{emergin} \mathrm{g}$ markets, $\mathrm{AE}-$ advanced economies. 


\section{Table 2. Variables and Their Sources}

\begin{tabular}{lll}
\hline Variable & \multicolumn{1}{c}{ Definition } & Source \\
\hline ER & $\begin{array}{l}\text { Exchange rate of the local currency vis-à-vis the US dollar } \\
\text { (daily average) }\end{array}$ & $\begin{array}{l}\text { International Financial } \\
\text { Statistics, IMF }\end{array}$ \\
CPI & $\begin{array}{l}\text { Consumer price index (seasonally adjusted, base month is } \\
\text { January, 2010) }\end{array}$ & $\begin{array}{l}\text { International Financial } \\
\text { Statistics, IMF }\end{array}$ \\
DEFACTO & De-facto exchange rate classification & Annual Report of Exchange \\
& & Arrangements and \\
& & Exchange Restrictions, IMF \\
\hline
\end{tabular}

Note: The sa mple includes seven CCA countries (Armenia, Azerbaijan, Georgia, Kazakhstan, Kyrgyz Republic, Tajikistan, a nd Uzbekistan) over the period January 1995-May 2020. 
Table 3. Summary of Main Results

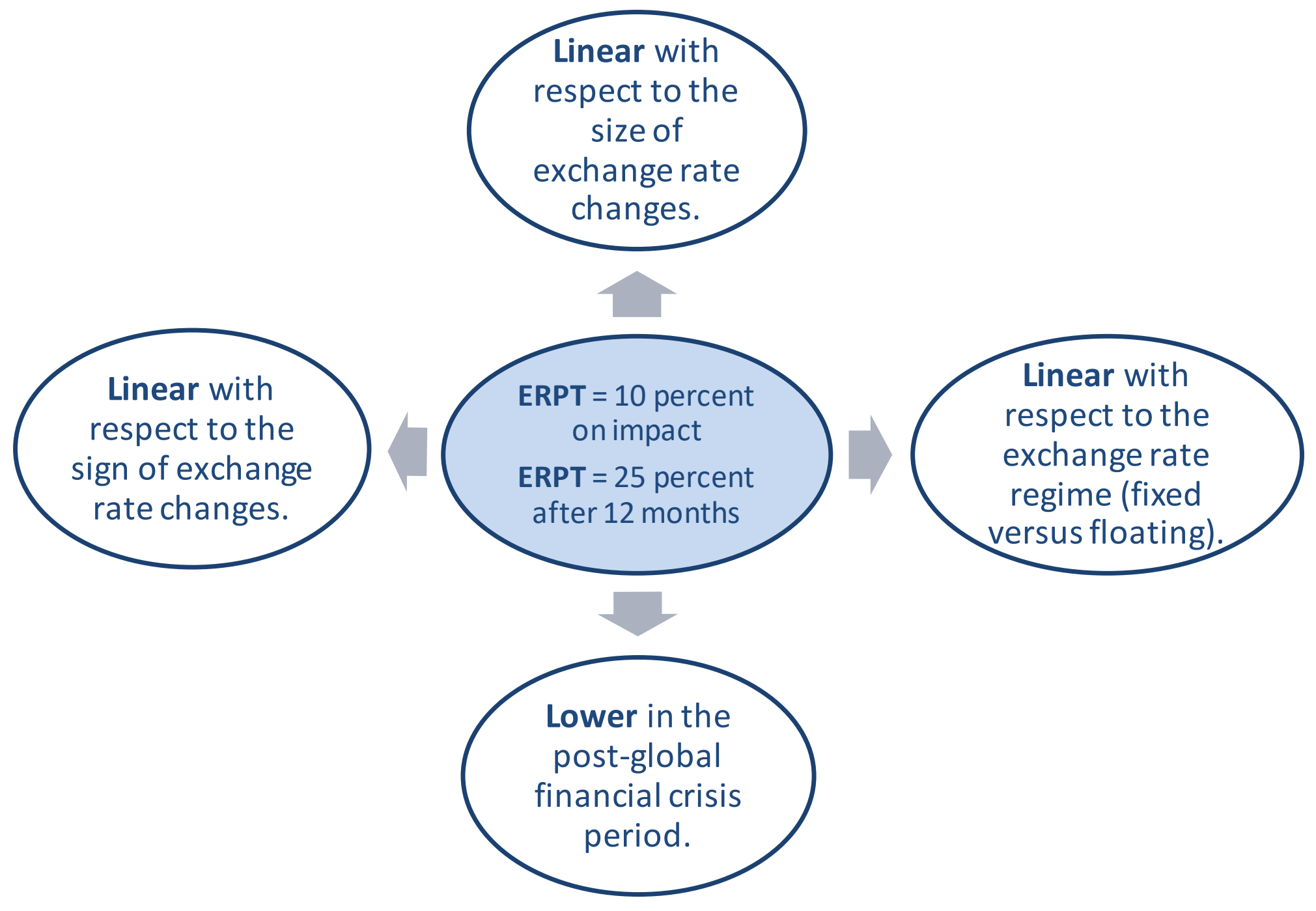




\section{References}

Aron, J., Macdonald, R. and J. Muellbauer. 2014. "Exchange Rate Pass-Through in Developing and Emerging Markets: A Survey of Conceptual, Methodological and Policy Issues, and Selected Empirical Findings." Journal of Development Studies, 50(1): pp. 101-43.

Barhoumi, K. 2006. "Differences in Long Run Exchange Rate Pass-Through into Import Prices in Developing Countries: An Empirical Investigation.” Economic Modeling, 23: pp. 926-51.

Beirne, J. and M. Bijsterbosch. 2011. "Exchange Rate Pass-Through in Central and Eastern European EU Member States.” Journal of Policy Modeling, 33: pp. 241-54.

Ben Cheikh, N. (2012). "Asymmetric Exchange Rate Pass-Through in the Euro Area: New Evidence from Smooth Transition Models.” Economics - The Open-Access, OpenAssessment E-Journal, 6: pp. 1-28.

Burstein, A. and G. Gopinath. 2014. "International Prices and Exchange Rates." In Gopinath, G., Helpman, E., and Rogoff, K., eds., Handbook of International Economics, $4^{\text {th }}$ edition, (4): pp. $391-451$.

Bussiere, M. 2013. "Exchange Rate Pass-Through to Trade Prices: The Role of Nonlinearities and Asymmetries." Oxford Bulletin of Economics and Statistics, 75(5): pp. $731-58$.

Calvo, G. and C. Reinhart. 2011. "Fear of Floating.” Quarterly Journal of Economics, 117(2): pp. 379-408.

Caselli, F. and A. Roitman. 2016. "Non-Linear Exchange Rate Pass-Through in Emerging Markets." IMF Working Paper WP/16/1 (Washington, D.C.).

Choudhri, E. and D. Hakura. 2006. "Exchange Rate Pass-Through to Domestic Prices: Does the Inflationary Environment Matter?" Journal of International Money and Finance, 25 (4): pp. 614-39.

Comunale, M. and H. Simola. 2018. "The Pass-Through to Consumer Prices in CIS Economies: The Role of Exchange Rates, Commodities and other Common Factors." Research in International Business and Finance, 44: pp. 186-217.

Delatte, A.-L. and A. Lopez-Villavicencio. 2012. "Asymmetric Exchange Rate PassThrough: Evidence from Major Countries." Journal of Macroeconomics, 34(3): pp. 833-44.

Goldberg, P. and M. Knetter. 1997. "Goods Prices and Exchange Rates: What Have We Learned?” Journal of Economic Literature, 35(3): pp. 1243-72. 
Ito, T. and K. Saito. 2008. "Exchange Rate Changes and Inflation in Post-Crisis Asian Economies: Vector Autoregression Analysis of the Exchange Rate Pass-Through" Journal of Money, Credit and Banking, 40(7): pp. 1407-38.

Jasova, M., Moessner, R. and E. Takats. 2019. "Exchange Rate Pass-Through: What Has Changed Since the Crisis?" International Journal of Central Banking, 15(3): pp. $27-$ 58 .

Jorda, O. 2005. "Estimation and Inference of Impulse Responses by Local Projections." American Economic Review, 95(1): pp. 161-182.

Kilic, R. 2016. "Regime-Dependent Exchange-Rate Pass-Through to Import Prices." International Review of Economics and Finance, 41: pp. 295-308.

Kohlscheen, E. 2010. "Emerging Floaters: Pass-Throughs and (Some) New Commodity Currencies.” Journal of International Money and Finance, 29: pp. 1580-95.

Razafimahefa, I. 2012. "Exchange Rate Pass-Through in Sub-Saharan African Economies and its Determinants.” IMF Working Paper WP/12/141 (Washington, D.C.).

Taylor, J. 2000. "Low Inflation, Pass-Through, and the Pricing Power of Firms." European Economic Review, 44(7): pp. 1389-1408. 